\title{
TREATMENT OF NON-GONOCOCCAL URETHRITIS WITH INTRAMUSCULAR TETRACYCLINE (TERRAMYCIN)*
}

\author{
BY \\ R. S. MORTON \\ The Royal Hospital, Sheffield
}

The place of oral oxytetracycline hydrochloride (Terramycin) therapy in the treatment of nongonococcal urethritis (N.G.U.) is well established (Harkness, 1953; Willcox, 1957; Morton and Read, 1957). Success rates of about 85 per cent. are above those obtained by other antibiotics, sulphomanides, or a combination of these.

The trial reported below was undertaken at a time when a degree of penicillin resistance was being reported in the treatment of gonococcal urethritis (King, 1958; Curtis and Wilkinson, 1958). The continued success of streptomycin in gonorrhoea was also questioned (Alergant, 1958). At this time, therefore, a need to treat gonorrhoea with a different antibiotic seemed likely to arise. Terramycin appeared to be the best choice, as its success in the treatment of gonorrhoea was well recognized (Willcox, 1957; Marmel and Prigot, 1955), and it had the added advantage that it would probably prevent the appearance of N.G.U. after the successful treatment of gonococcal urethritis. Intramuscular tetracycline (Achromycin) used by Marmell and Prigot (1955) gave rise to local pain, and a trial of intramuscular terramycin therapy was therefore undertaken.

\section{Material}

A series of 48 white males with N.G.U. was treated. The average age was 31 years (range 17-64), and 16 were married, 24 single, and eight separated or widowed. In ten cases there was a history of previous N.G.U., and seven had had gonorrhoea. The apparent source of infection was extramarital in 36 , marital in nine, and doubtful in three. In so far as the incubation period could be determined, it was less than 10 days in 28 , over 10 days in ten, and doubtful in ten. In all but two cases, the duration of the urethral discharge was less than 10 days. In all cases the urethritis was well marked, the discharge being purulent in nine and muco-purulent in 39. In nine cases the two-glass urine test showed a haze of pus in both glasses, and in 32 there was a haze in the first glass only. (Seven patients were unable to provide a sample). Complications such as epididymitis or Reiter's disease were not noted.

\footnotetext{
* Short paper read to M.S.S.V.D. on October 28, 1960.
}

\section{Management}

Gonorrhoea was excluded by a Gram-stained smear of the urethral discharge. A routine Wassermann reaction, a Kahn test or Price's Precipitation reaction were carried out in all cases. Patients were instructed to attend for daily injections of oxytetracycline hydrochloride (Terramycin) for 4 consecutive days, and thereafter for surveillance. All injections were given in the upper and outer quadrant of the buttock. The routine dosage was $200 \mathrm{mg}$. per injection, but six cases received $100 \mathrm{mg}$., and six had $250 \mathrm{mg}$. A variety of local anaesthetic vehicles was tried, viz. 2 per cent. procaine hydrochloride, 2 per cent. xylocaine, and a preparation preconstituted with 2 per cent. lidocaine (proprietary name for xylocaine). In some cases the dose was divided, half being given in each buttock. These subsidiary trials were made in an effort to prevent or minimize local pain and stiffness.

\section{Results}

Of the 48 cases treated, 36 completed the prescribed course of treatment, five defaulted during therapy, and in seven treatment was discontinued because of local pain and/or stiffness. Seven of those completing the course also complained of a local reaction.

Of the 36 who completed the course, four showed no response, and of the 32 who responded to treatment five had a later recurrence. Little difference was noted in the response rate with variation of dosage, the overall success rate being 88 per cent. (Table I).

TABLE I

ANALYSIS OF RESPONSE TO INTRAMUSCULAR TERRAMYCIN IN NON-GONOCOCCAL URETHRITIS

\begin{tabular}{|c|c|c|c|c|c|c|c|c|}
\hline \multicolumn{5}{|c|}{ Result } & \multirow{2}{*}{$\begin{array}{c}\text { No. } \\
\text { of } \\
\text { Cases }\end{array}$} & \multicolumn{3}{|c|}{$\begin{array}{c}\text { Daily Dosage for } 4 \\
\text { days (mg.) }\end{array}$} \\
\hline & & & & & & 100 & 200 & 250 \\
\hline $\begin{array}{l}\text { Success } \\
\text { Failure } \\
\text { Defaulted } \\
\text { Treatment }\end{array}$ & $\begin{array}{l}\ddot{x} \\
\dot{\text { Discon }}\end{array}$ & $\begin{array}{l}\cdots \\
\ddot{0} \\
\text { atinued }\end{array}$ & $\begin{array}{l}\cdots \\
\cdots \\
\cdots\end{array}$ & $\begin{array}{l}\ddot{*} \\
\ddot{*}\end{array}$ & $\begin{array}{r}32 \\
4 \\
5 \\
7\end{array}$ & $\begin{array}{l}5 \\
1 \\
-\end{array}$ & $\begin{array}{r}24 \\
2 \\
4 \\
6\end{array}$ & $\begin{array}{l}3 \\
1 \\
1 \\
1\end{array}$ \\
\hline Total & .. & $\ldots$ & $\ldots$ & $\ldots$ & 48 & 6 & 36 & 6 \\
\hline
\end{tabular}


The follow-up examination of the 32 patients who completed a successful course of treatment varied from a few days to 3 months. Thirty ( 93 per cent.) were followed for one week or more, 25 ( 78 per cent.) for 2 weeks or more, and ten (31 per cent.) for 9 weeks or more. The recurrence rate of 15 per cent. compares with the 16 per cent. reported by Morton and Read (1957), who used oral terramycin in 250-mg. doses, 6-hrly for 4 days.

Side-Effects. - The incidence of local reaction varied little with the dosage (Table II).

\section{TABLE II}

LOCAL REACTION TO INTRAMUSCULAR TERRAMYCIN IN 48 CASES OF NON-GONOCOCCAL URETHRITIS

\begin{tabular}{l|l|lll|c|c|c|c}
\hline Daily Dosage (mg.) &.. &. &. & 100 & 200 & 250 & Total \\
\hline $\begin{array}{l}\text { No. of Cases } \\
.\end{array}$ &. &.. &.. & 6 & 36 & 6 & 48 \\
\hline $\begin{array}{l}\text { Local } \\
\text { Reactions }\end{array}$ & Treatment discontinued & & 5 & 2 & 7 \\
\cline { 2 - 7 } & Treatment completed &.. & 1 & 4 & 2 & 7 \\
\hline
\end{tabular}

Altogether, fourteen men complained of pain or stiffness at or around the site of injection, and in seven treatment had to be discontinued.

Five patients defaulted before completing the 4-day course, and whether this was due to a satisfactory response, or a local reaction, or both, is not known. The cause of local pain is stated by the manufacturers to be the hypertonic nature of the solution, the presence of magnesium ions, and the low $\mathrm{pH}$. Efforts to overcome this difficulty with local anaesthetics such as 2 per cent. Procaine, 2 per cent. xylocaine, or 2 per cent. Lidocaine preconstituted with the terramycin failed (Table III). There was little to choose between these vehicles.

TABLE III

EFFECT OF ANAESTHETICS ON LOCAL REACTION

\begin{tabular}{c|c|c|c}
\hline Anaesthetic & $\begin{array}{c}\text { No. } \\
\text { of } \\
\text { Cases }\end{array}$ & $\begin{array}{c}\text { Pain or Stiffness } \\
\text { (Treatment } \\
\text { completed) }\end{array}$ & $\begin{array}{c}\text { Pain and Stiffness } \\
\text { (Treatment } \\
\text { discontinued) }\end{array}$ \\
\hline $\begin{array}{c}\text { per cent. } \\
\text { Procaine }\end{array}$ & 21 & 3 & 1 \\
\hline $\begin{array}{c}2 \text { per cent. } \\
\text { Xylocaine }\end{array}$ & 13 & 2 & 4 \\
\hline $\begin{array}{c}2 \text { per cent. } \\
\text { Lidocaine } \\
\text { Preconstituted }\end{array}$ & 14 & 2 & 2 \\
\hline Total & 48 & 7 & 7 \\
\hline
\end{tabular}

Apart from the local reactions there were no such side-effects as are usually encountered with oral terramycin therapy.

\section{Summary and Conclusions}

(1) 48 cases of non-gonococcal urethritis (N.G.U.) were treated with intramuscular oxytetracycline hydrochloride (brand Terramycin); 36 had doses of $200 \mathrm{mg}$., six had doses of $100 \mathrm{mg}$., and six had doses of $250 \mathrm{mg}$. daily for 4 days.

(2) 36 patients completed the course of treatment, with immediate success in 32 ( 88 per cent.). Five (15 per cent.) of these 32 successes had a recurrence later. These results compare favourably with those obtained by oral Terramycin therapy.

(3) Side-effects were confined to local reactions presenting as pain and/or stiffness, which occurred in fourteen patients ( 30 per cent.). In seven cases the reaction was severe enough to warrant discontinuation of treatment. The incidence of pain and stiffness did not vary greatly with dosage or with the local anaesthetic vehicle used.

(4) Until the difficulty of painful injections is overcome, intramuscular Terramycin in the dosages used cannot be recommended as routine treatment.

My thanks are due to Dr. F. R. Fletcher, of Pfizer Ltd., for supplying the Terramycin used in this study.

\section{REFERENCES}

Alergant, C. D. (1958). Brit. J. vener. Dis., 34, 36.

Curtis, F. R., and Wilkinson, A. E. (1958). Ibid., 34, 70. Harkness, A. H. (1953). Ibid., 29, 134.

King, A. J. (1958). Lancet, 1, 651.

Marmell, M., and Prigot. A. (1955). Brit. J. vener. Dis., 31, 188 .

Morton, R. S., and Read, L. (1957). Ibid., 33, 223.

Willcox, R. R. (1957). Acta derm.-venereol. (Stockh.), 37, 332.

Le traitement de l'urétrite non-gonococcique par la tétracyline intramusculaire (Terramycine)

\section{Résumé}

(1) Le chlorhydrate d'oxytétracycline (Terramycine) fut injecté par voie intramusculaire dans 48 cas atteints d'urétrite non-gonococcique; 36 malades reçurent 200 mg., 6 reçurent $100 \mathrm{mg}$. et 6 reçurent $250 \mathrm{mg}$. par jour pendant 4 jours.

(2) 36 malades suivirent le traitement jusqu'au bout et le succès fut immédiat dans 32 cas $(88 \%)$. Il y eut une récidive dans 5 de ces 32 cas $(15 \%)$. Ces résultats supportent bien la comparaison avec eux que l'on obtient en administrant la Terramycine par la bouche.

(3) Des complications, limitées à des réactions locales comme des douleurs et/ou des raideurs, furent présentes dans 14 cas $(30 \%)$. Dans 7 cas, la sévérité de la réaction justifia l'abandon du traitement. L'incidence des douleurs et des raideurs ne varia pas beaucoup ni avec le dosage ni avec l'agent anesthésique.

(4) Tant qu'on n'aura pas réussi à rendre les injections de Terramycine indolores, on ne saurait recommander l'emploi courant des doses ci-dessus. 